\title{
A NEW APPROACH TO THE NORTHERN SPRUCE REGENERATION PROBLEM ${ }^{1}$
}

\author{
By HENRI LEBLANC ${ }^{2}$
}

Born in Kamouraska, Quebec; received B.A. certificate in 1940, Levis College; graduated in forestry at Laval University in 1944; took Master Degree (Silviculture) Laval, 1953. Experience: Forester one year with AngloCanadian Pulp \& Paper Mills; worked as extension forester one year for Quebec Extension Bureau; worked four years as cruiser for different firms throughout the province of Quebec; and joined Canadian International Paper Company's staff as research forester, a post he is presently holding.

\section{ABSTRACT}

Lack of reproduction of black spruce, Picea mariana, in pure black spruce stands in old cut-over areas, has always been a great subject of discussion and one for intensive work among foresters. Many reasons such as the absence of an adequate seed supply stored on top of humus, or adverse germination conditions are said to be partly responsible.

This study on the humus of this unregenerated cut-over area, indicates clear cutting of this stand will influence the normal concentration of definite micro-nutrients such as manganese and magnesium.

The augmentation of manganese in the soil has a detrimental effect on the growth of plants when. its concentration is too high. The diminution of magnesium, which is an element necessary to stimulate the growth, must create abnormal nutritive conditions of the habitat. This visible lack of equilibrium might be the cause of the absence of seedlings of Picea mariana on certain parts of this cut-over area.

This paper is dealing with a regeneration problem encountered especially in our Milieu forest in the St. Maurice watershed.

In this study all our stands are classified by forest site types belonging to different plant associations. By plant associations we mean a concept of vegetation grouping, presenting the same floristic composition as defined by BraunBlanquet. Each plant association is divided into practical units called forest site types.

\section{History Of The Stand And Method Of Work}

According to our findings, the area under study was burnt around 1865. A few patches located in the low lands were not burnt out by the fire. These residual patches are unevenaged and from 120 to 180 years. Nothing can be determined about the stand prior to that fire. It seems that this fire was beneficial to the enlargement of areas of Picea mariana. Through the burnt area scattered patches of Pinus Banksiana developed, showing a much more severe destruction of the humus layers. On upper slopes, intolerant hardwood species reclothed the soil, followed by an under-story of softwood species actually pre-

\footnotetext{
${ }^{1}$ Paper based on Master's thesis from Laval University, 1953. Acknowledgment is made to Dr. A. Lafond and Dr. A. Richard for help and direction.

Silviculturist, Canadian International Paper Company, Trois-Rivieres, Quebec.

Manuscript received for publication July 19, 1954.
} 
senting a mixedwood cover type classified in the Cornus-Maianthemum forest site type.

Those stands were mostly harvested in 1941 by the clear cutting system. In 1950, a regeneration survey indicated that the reproduction of softwood species was very good in the Cornus-Maianthemum type, but unsatisfactory, sometimes entirely missing in the Calliergon-Kalmia type.

In order to find out the cause of this lack of reproduction, we decided to analyse the humus of this forest site type as found before the cut and after the cut. Two other forest site types were analysed at the same time to be used as guides in the interpretation of our results: a rich site, Cornus-Maianthemum, where the reproduction and growth of Picea mariana are very good and a poor site, Sphagnum-Carex where the reproduction of Picea mariana is mostly assured from layerings.

Humus samples were collected in 1951 and analysed at Laval Forestry School during the winter 1952. Standard methods were used to determine the content of the principal elements in the humus: $\mathrm{Mg}, \mathrm{Mn}, \mathrm{Fe}, \mathrm{K}, \mathrm{P}$. Modern equipment was utilized to measure $\mathrm{pH}$ and Oxydo-Reduction potential values.

\section{EXPERIMENTAL RESULTS}

Table No. 1 shows the $\mathrm{pH}$ value, the Oxydo-Reduction Potential value, the percentage of organic matter, the percentage of total nitrogen, the carbonnitrogen ratio and finally the assimilable phosphorus for each sample studied.

The two forest site types chosen allow a comparison between the CalliergonKalmia forest site type and Sphagnum-Carex forest site type, a rather poor site type, sometimes unmerchantable and Cornus-Maianthemum, a site type of excellent quality.

We see from table No. 1 that the $\mathrm{pH}$ value is the same for both types: Sphagnum-Carex and Calliergon-Kalmia. The $\mathrm{pH}$ value is however higher in the Cornus-Maianthemum type. This $4.6 \mathrm{pH}$ value is high when compared to the values in the Calliergon-Kalmia and Sphagnum-Carex types which have a $\mathrm{pH}$ value of 3.5 and 3.6 respectively. The cause of this difference of acidity in Cornus-Maianthemum can be the high quantity of cations contained in the leaves of Cornus Canadensis and of Betula paperyfera which each year fall to the ground. (Gagnon, 1953).

There is, nevertheless, a variation of the $\mathrm{pH}$ value in the humus of Calliergon-Kalmia after the cut. The decreasing acidity value could possibly be the result of the clear cutting.

The rather high percentage of organic matter is the same in the two forest site types of the softwood stands, but it is of lower value in the Cornus-Maianthemum site type of the mixedwood forest. Apparently the clear-cutting of the area did not alter the volume of organic matter in the Calliergon-Kalmia type.

Theoretically a full exposure of humus cover by the clear-cutting method should have favored a faster decomposition of the organic matter, and therefore, a reduction of the organic matter percentage. On the contrary, the results show 
TABLE I

Showing the pH Value, the Oxydo-Reduction Potential, the Per Cent of Organc Matter, the Per Cent of Total Nitrogen, C/N Ratio, and Assimilable Phosphorus

\begin{tabular}{|c|c|c|c|c|c|c|c|}
\hline $\begin{array}{c}\text { Forest Site } \\
\text { Type }\end{array}$ & 总 & 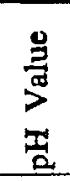 & 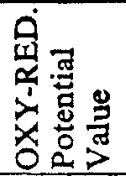 & 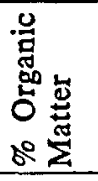 & 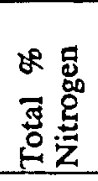 & 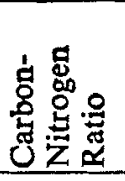 & 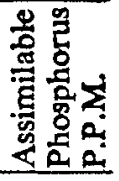 \\
\hline \multirow{2}{*}{$\begin{array}{c}\text { Calliergon- } \\
\text { Kalmia }\end{array}$} & 1 & 3.9 & -188 & 94 & 1.28 & 40 & 55 \\
\hline & 2 & 4.2 & -190 & 90 & 1.21 & 40 & 57 \\
\hline \multirow{2}{*}{ Cut } & 3 & 3.9 & -214 & 80 & 1.18 & 37 & 60 \\
\hline & 4 & 3.8 & -218 & 95 & 1.18 & 44 & 69 \\
\hline \multirow{2}{*}{$\begin{array}{c}\text { Calliergon- } \\
\text { Kalmia } \\
\text { Uncut } \\
\end{array}$} & 5 & 3.5 & -188 & 95 & 1.09 & 47 & 78 \\
\hline & 6 & 3.6 & -196 & 83 & 1.34 & 33 & 68 \\
\hline \multirow{2}{*}{$\begin{array}{l}\text { Sphagnum- } \\
\text { Carex }\end{array}$} & 7 & 3.6 & -250 & 87 & 1.25 & 39 & 88 \\
\hline & 8 & 3.7 & -219 & 83 & 1.36 & 33 & 81 \\
\hline \multirow{3}{*}{$\begin{array}{l}\text { Cornus- } \\
\text { Maianthemum }\end{array}$} & 9 & 4.8 & -201 & 84 & 2.07 & 22 & 59 \\
\hline & 10 & 4.5 & -191 & 82 & 1.85 & 24 & 62 \\
\hline & 11 & 4.5 & -186 & 76 & 1.76 & 23 & 78 \\
\hline
\end{tabular}

a constant rate of the organic matter which is confirmed by an identical percentage of total nitrogen.

The total nitrogen percentage is higher in the Cornus-Maianthemum type than in the two other types compared. It is of the same value in the CalliergonKalmia before as after the cut. In the soils, the percentage of total nitrogen depends on the amount of the organic matter. This element, present as organic compound, is kept in the structure of tissues and cannot be assimilated directly by the plants. It is, therefore, necessary that plant materials and debris should be broken by microorganisms to facilitate the liberation of nitrogen. The more the organic matter is decomposed the higher the nitrogen percentage will be.

In most of our forest soils, nitrogen is the limiting factor of the growth of trees. It conditions the utilization of nutrients present in the soils.

The carbon-nitrogen ratio, which value is 40 , indicates pretty well the degree of fertility of this Calliergon-Kalmia type, before as well as after the cut. In general, a C/N ratio value close to 25 is the indication of a fertile site. This value is minimum for soils which have a pH value varying between 5 and 
TABLE II

Content of Main Nutritive Elements: (Fe - Mg - Mn - Ca - K)

EXPRESSED IN P.P.M. AND THE QUANTITY OP

EXchanoeable H IONS IN M.E. PER 100 grs.

\begin{tabular}{|c|c|c|c|c|c|c|c|}
\hline $\begin{array}{c}\text { Forest Site } \\
\text { Type }\end{array}$ & 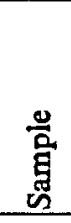 & 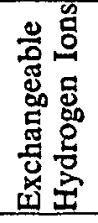 & 迹离 & 戠䁶 & 昰宽 & ช & 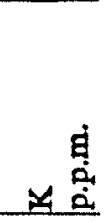 \\
\hline \multirow{3}{*}{$\begin{array}{l}\text { Calliergon- } \\
\text { Kalmia }\end{array}$} & 1 & 152 & 63 & 54 & 136 & 285 & 200 \\
\hline & 2 & 117 & 68 & 105 & 235 & 565 & 230 \\
\hline & 3 & 116 & 180 & 50 & 158 & 837 & 510 \\
\hline Cut & 4 & 131 & 121 & 66 & 204 & 625 & 250 \\
\hline \multirow{2}{*}{$\begin{array}{c}\text { Callergon- } \\
\text { Kalmia } \\
\text { Uncut }\end{array}$} & 5 & 171 & 62 & 83 & 60 & 475 & 570 \\
\hline & 6 & 135 & 77 & 158 & 108 & 660 & 745 \\
\hline \multirow{2}{*}{$\begin{array}{l}\text { Sphagnum- } \\
\text { Carex }\end{array}$} & 7 & 125 & 122 & 38 & 10 & 248 & 375 \\
\hline & 8 & 94 & 132 & 123 & 438 & 687 & 1055 \\
\hline \multirow{3}{*}{$\begin{array}{l}\text { Cornus- } \\
\text { Maianthemum }\end{array}$} & 9 & 72 & 135 & 152 & 428 & 790 & 1030 \\
\hline & 10 & 93 & 88 & 143 & 232 & 700 & 915 \\
\hline & 11 & 79 & 148 & 163 & 143 & 730 & 980 \\
\hline
\end{tabular}

7. Any $\mathrm{pH}$ value outside this range means a diminishing class of fertility, that is to say, a slackening in the rate of decomposition of organic matter and then, a reduced liberation of assimilable nutrients by the plants. This $\mathrm{C} / \mathrm{N}$ ratio is of lower value in the Cornus-Maianthemum type and will indicate better conditions for the growth of plants in this type.

No differences were found in the Oxydo-Reduction potential values.

The assimilable phosphorus is less concentrated in the Cornus-Maianthemum type. In the three forest site types studied, the humus content in phosphorus is rather light. It seems that this anion is absorbed and assimilated faster by the plants. Wilde, 1946, claims that hardwood species require more phosphorus than softwood species.

Table No. 2 shows the content in p.p.m. (parts per million) of the main assimilable nutrients and also the measure of exchangeable hydrogen ions expressed in miliequivalents per 100 grams. The main nutritive elements considered are: iron, manganese, magnesium, calcium and potassium. 
There are evidences of differences in some nutrients in the humus collected in cut and uncut areas in the Calliergon-Kalmia forest site type. The effects of the clear cutting treatment could be measured by a decrease of the exchangeable hydrogen ions concentration, by a double increase of manganese, by an increase of iron concentration and finally, a sensible decrease of magnesium and potassium. Only the calcium content does not vary.

Discussion OF Results

To make the discussion of results presented in Tables $1 \& 2$ easier, we determined the arithmetic mean of each measured property and we grouped these means in Table No. 3 .

TABLE III

Artrhmetic Mean of Physico-Chemical Properties of Humus'Samples Studied.

\begin{tabular}{|c|c|c|c|c|c|c|c|}
\hline $\begin{array}{l}\text { Forest Site } \\
\text { Type }\end{array}$ & 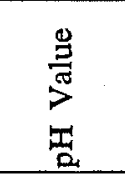 & 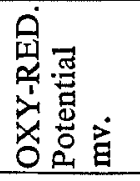 & 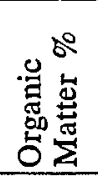 & 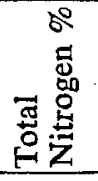 & 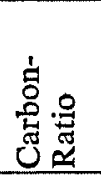 & 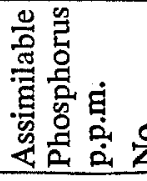 & 总咅 \\
\hline $\begin{array}{l}\text { Calliergon- } \\
\text { Kalmia-Cut }\end{array}$ & 3.9 & -202 & 88 & 1.21 & 40 & 60 & 4 \\
\hline $\begin{array}{l}\text { Calliergon- } \\
\text { Kalmia- } \\
\text { Uncut }\end{array}$ & 3.5 & -192 & 89 & 1.21 & 40 & 73 & 2 \\
\hline $\begin{array}{l}\text { Sphagnum- } \\
\text { Carex }\end{array}$ & 3.6 & -234 & 85 & 1.30 & 36 & 85 & 2 \\
\hline \multirow[t]{2}{*}{$\begin{array}{l}\text { Cornus- } \\
\text { Maianthemum }\end{array}$} & 4.6 & -192 & 80 & 1.89 & 23 & 66 & 3 \\
\hline & 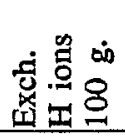 & 薃 & $\stackrel{g}{\dot{a}}$ & 贺宫 & $\checkmark \stackrel{\dot{a}}{\dot{\dot{a}}}$ & 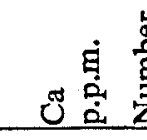 & 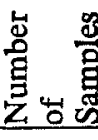 \\
\hline $\begin{array}{l}\text { Calliergon- } \\
\text { Kalmia-Cut }\end{array}$ & 129 & 108 & 183 & 68 & 243 & 578 & 4 \\
\hline $\begin{array}{l}\text { Calliergon- } \\
\text { Kalmia- } \\
\text { Uncut }\end{array}$ & 153 & 69 & 84 & 120 & 657 & 567 & 2 \\
\hline $\begin{array}{l}\text { Sphagnum- } \\
\text { Carex }\end{array}$ & 109 & 127 & 224 & 80 & 725 & 467 & 2 \\
\hline $\begin{array}{l}\text { Cornus- } \\
\text { Maianthemum }\end{array}$ & 81 & 123 & 267 & 152 & 975 & 740 & 3 \\
\hline
\end{tabular}


A statistical analysis of these differences of means shows that there is a significant difference for some nutritive elements found in the cut areas and the uncut areas of the Calliergon-Kalmia type. Table 4 presents the statistical results and shows the value of " $t$ " for the means of the four elements: $\mathrm{K}, \mathrm{Mg}$, $\mathrm{Mn}, \mathrm{Fe}$. The differences in manganese and potassium are evident.

The difference in the concentration of iron and magnesium, before the cut and after the cut, are quite important but not significant. In our forest soils, the magnesium-calcium ratio is supposed to vary between 0.2 to 0.3 (Wilde, 1946). This proportion exists in the Cornus Maianthemum type and in the Calliergon-Kalmia type, before the cut. After the cut, in this latter type, the

TABLE IV

Value of " $\mathrm{t}$ " from Státistical InTERPRetation of the Dipferences of the Means for the Following Elements: $\mathrm{K}, \mathrm{MN}_{\mathrm{N}}$, Mg, $\mathrm{Fe}$.

\begin{tabular}{|c|c|c|c|c|c|c|c|}
\hline & 胥 & 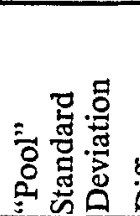 & 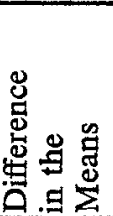 & 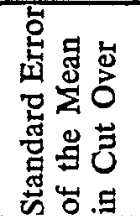 & 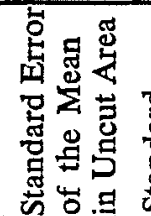 & 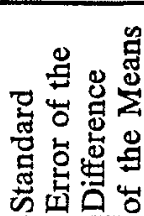 & 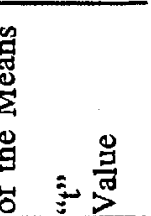 \\
\hline $\mathrm{K}_{\text {Uncut }}^{\text {Cut }}$ & 243 & 175 & 414 & 87 & 123 & 150 & $\begin{array}{l}2.8 \\
\quad \text { signif. }\end{array}$ \\
\hline $\begin{array}{l}\text { Cut } \\
\text { Mn } \\
\text { Uncut }\end{array}$ & $\begin{array}{r}183 \\
84\end{array}$ & 42 & 99 & 21 & 30 & 37 & $\begin{array}{l}2.7 \\
\quad \text { signif. }\end{array}$ \\
\hline $\begin{array}{l}\text { Cut } \\
\text { Mg } \\
\text { Uncut }\end{array}$ & $\begin{array}{r}68 \\
120\end{array}$ & 33 & 52 & 16 & 23 & 28 & $\begin{array}{l}1.2 \\
\text { Un-sign. }\end{array}$ \\
\hline $\begin{array}{l}\text { Cut } \\
\mathrm{Fe} \\
\text { Uncut }\end{array}$ & $\begin{array}{r}108 \\
69\end{array}$ & 47 & 39 & 23 & 33 & 40 & $\begin{array}{l}1.0 \\
\text { Un-sign. }\end{array}$ \\
\hline
\end{tabular}

Degree of Freedom: 4

ratio is not any more than 0.1 . In the Sphagnum-Carex type the same ratio $(\mathrm{Mg} / \mathrm{Ca})$ is smaller than 0.2 ; in fact, it gives 0.17 and we can already notice an inferior rate of growth. The magnesium is considered as an element which stimulates the growth.

The content in iron shows a tendency opposite to that of magnesium. When the latter element decreases after the cut, the former increases. This increase of iron which was found non significant in the statistical interpretation has however an influence on the iron/potassium ratio. This ratio is 0.10 before the cut and can be compared with those of Cornus-Maianthemum 0.13 and Sphagnum-Carex 0.18. After the cut, in Calliergon-Kalmia, this ratio almost quadruples and reaches a maximum of 0.44 . 
This variation of iron/potassium and magnesium/calcium ratios show us an important change in the conditions of the soils. Our actual knowledge does not permit us to interpret physiologically the effect of this change on the metabolism of the plants.

However, the differences of the means before and after the cut were found significant for manganese and potassium.

We do not know very precisely the part played by manganese in plants. We find it in small quantities in the plant tissues and we believe that an excess of manganese in the soil would be toxic to the plants. The part played by this element on plants is better known when it is lacking in the soil.

Unfortunately, up to date, there has been no research work done in order to determine at which point of concentration the manganese in the soils becomes toxic to the seedlings of Picea mariana.

However, we see by Table No. 3, that the concentration of manganese doubles after the cut and comes near to the content of this element in the Sphagnum-Carex type. It is worth remarking that in this latter type, the reproduction of Picea mariana is assured much more from layerings than from the germination of seeds.

The part played by the potassium in plants, although undetermined, is not less essential (Hoagland, 1948). We usually consider that it chiefly activates the enzymatic reactions. Wilde (1946) claims it is necessary in the formation and utilization of sugar and starch as well as for the synthesis of proteins in the plants. Its absence would slow the cellular division.

The clear cut in Calliergon-Kalmia type has brought about an obvious decrease in the assimilable potassium. Before the cut, the quantity of potassium contained in the humus of that type is comparable to that one found in CornusMaianthemum. After the cut, the quantity of the potassium is three to four times less.

We also notice that the iron/manganese and manganese/calcium ratios decrease under the effect of the cut whereas the iron/potassium and manganese/ calcium ratios increase. The variations of these ratios certainly indicate a considerable change in equilibrium of the soil.

We do not know, either, the influence the manganese can have on the potassium in the soil.

The lack of reproduction of Picea Mariana in the Calliergon-Kalmia type shows the importance of undertaking some laboratory research and also of cultivating some seedlings of Picea Mariana in the soils of which the concentration of manganese and potassium would be known. Some cultures could also be done with manganese and iron. These two cations form a pair: the last one is supposed to neutralize the action of the first. It would be important to find out which part is played by one or the other towards its opposite and to determine at which concentration in the soil, this couple becomes non-efficient. 


\section{CONCLUSIONS}

This comparative study of Calliergon-Kalmia forest site type before and after the cut permits the following conclusions:

The clear cut has had no apparent effect on certain physico-chemical properties such as: the percentage of organic matter, the total nitrogen, the carbon/nitrogen ratio and the assimilable phosphorus. Only the acidity of humus has decreased slightly.

The effects of the clear cut make themselves felt only in the variation of the amount of nutritive elements assimilable in the humus. Of the five principal elements studied, only the calcium remained constant before and after the cut.

The augmentation of manganese in the soil has a detrimental effect on the growth when its concentration is too high, and the diminution of magnesium, which is an element necessary to stimulate the growth, must create abnormal nutritive conditions of the habitat. This visible lack of equilibrium might be the cause of the absence of seedlings of Picea mariana on certain surfaces of this cut over area.

We probably should verify to a greater extent, by further analysis, to which point this tendency is true, and also to determine in laboratory, by cultures, the limit where manganese becomes toxic for the seedlings of Picea mariana.

An identical study should be done on the potassium to find out the minimum of concentration in the soil for the normal development of the seedlings of the species considered.

From a practical point of view, it would be interesting to establish some observation plots on the unregenerated cut over areas where the manganese would be rendered non-soluble by adding calcium. A fertilization of these soils by addition of potassium should give interesting results. 